\title{
IMPROVING STUDENTS' READING COMPREHENSION THROUGH RECIPROCAL TEACHING STRATEGY ON REPORT TEXT
}

\author{
Elisa Yulianti ${ }^{1}$, Eko Setiawan ${ }^{2}$ \\ ${ }^{1}$ IKIP Siliwangi \\ ${ }^{2}$ IKIP Siliwangi \\ ${ }^{1}$ elisayuli11@gmail.com, ${ }^{2}$ exobanxsalizer@gmail.com
}

\begin{abstract}
The objective of this research is to know how to use of reciprocal methods to teaching reading comprehension of the senior high school in second grade. The background of the research is to help students' to cope the difficulties in reading report text, because there are still many students who find it difficult to read English and the lack of reading comprehension of students in class XI Animation of SMK TI Garuda Nusantara Cimahi with the aim to know whether there is an increase in student scores after using the Reciprocal Learning method. The author uses the reciprocal method to increase the ability of students to read comprehension. This research is quantitative by using experimental research methods. After conducting the research obtained the data pre-test (80) and post-test (95). Based on these data, it can be concluded that the use of reciprocal methods in the report text material can improve reading comprehension in students of class XI Animation 2 Vocational School of TI Garuda Nusantara Cimahi.
\end{abstract}

Keywords: Reading comprehension, Report text, Reciprocal learning

\section{INTRODUCTION}

English is an international language that is used as a communication tool throughout the world, but is why English is a very important language to learn. People use language to express their emotions, feelings and ideas. No one can communicate internationally without using English, because almost all scientific books are written in English. Therefore in Indonesia, English lessons are one of the most important subjects to learn. In an article written by Bachrudin Musthafa, 2016 explained that the curriculum currently has goals and targets in English language lessons, namely enabling students to communicate politely in oral and written communication. English has four basic skills, namely listening, speaking, reading and writing. All of these skills are interconnected to improve their skills in communication.

Reading is one of the language skills that must be taught in English classes of high school students because reading is one of the language skills included in rhetoric like other language skills speaking and writing, Haryadi (2007) in Kamsari (2013). Urquhart (1998: 14) as cited in Parmawati and Yugafiati (2017) states that reading means dealing with language message in written or printed form.. Moreover, Campbell (1995) in Apsari (2016) adds that reading is the most is useful skill for foreign language learners since a reading skill mastery is the key for a successfull academic life, a widen horizon, and an access to new knowledge and information. Reading is an activity informed by the apprehension of images, shapes, patterns, and rhythms, which come to be recognized through repeated encounters and remembered forms; the meanings that are made in reading are in excess of the meanings that arise from the 
interpretation of written language (Lorange, 2014: 30) as cited in Parmawati (2018). Through teaching and learning to read, students are expected to be able to understand the readings they read. According to (Setiyaningsih, 2013), reading comprehension is a term used to identify those skills needed to understand and apply information contained in a written material. But in fact based on observations carried out by researchers at the SMK TI GARUDA NUSANTARA there are so many students who are still stuttering in reading because English is a language that is still unfamiliar to them, another problem is that there are still many students who find it difficult that section, looking for specific information, identifying key ideas, identifying explicit and implicit information in a text.

In addition, the activity of students in class is also a problem, students tend to be quiet and not dare to use English in answering teacher questions. Even though student activeness is the most important basic element to see how successful the teaching and learning process according to (Mulyasa, 2009) learning is said to be successful and quality if all or at least most students are actively involved, both physically, mentally and socially in the learning process .

Based on these problems it is necessary to develop an action that can improve students' reading skills and the activity of students in English lessons in the form of applying the Reciprocal learning model.According Palincsar \&Brown,1984 (in Rini, 1985), Reciprocal teaching is an instructional strategy based on modeling and guided practice in which the instructor first models a set of reading comprehension strategies and then gradually cedes responsibility for these strategies to the students. Pioneer reciprocal teaching researchers Palincsar and Brown (1984) developed this strategy to reinforce compreh ension in L1 and ESL reading classes. In other word, reciprocal teaching is a teaching technique in which the teacher leads a discussions of the text while modeling reading comprehension strategies then she begins to have the students take the role of teacher or dialoque reader. As students begin to lead the dialoque process, the teacher assumes the role of guide or facilitator, rather than leader.

Reciprocal teaching is an instructional approach designed to improve reading comprehension in which the students are encouraged to use reading strategy. According to Cole (1990). in the reciprocal teaching model, students were taught four independent understanding strategies, namely summarizing, asking questions and solving them, clarifying or explaining and predicting teaching materials. The details of the four independent understanding strategies are as follows:

\section{Summarizing}

In this understanding strategy students are given the opportunity to identify and make an overview of important information from a teaching material that has been read. These teaching materials can be summarized by students in the form of sentences and paragraphs that are made by themselves.

\section{Questioning}

In this comprehension strategy students think of important questions that can be asked from what they read and convincingly can answer the question.

\section{Clarifying}

In this understanding strategy students, note if there are things that are not clear or unreasonable from the reading section and then check whether we succeed in making it reasonable. 


\section{Predicting}

This understanding strategy occurs when students predict (guess) what the author might discuss in the next section of writing. Alternative Hypothesis says that the use of reciprocal teaching strategy increases the students' reading comprehension.

Based on the theoretical description above, the hypotheses are formulated as follows: (1) Null Hypothesis says that the use of Reciprocal teaching is not effective to improve teaching reading comprehension for senior high school; (2) Null Hypothesis says that the use of Reciprocal Teaching is effective to improve teaching reading comprehension for senior high school.

\section{METHOD}

This type of research is quantitative by using experimental research methods. This experimental research method is a method used to find the effect of certain treatments on others in controlled conditions (Sugiyono,2015). The experimental research method has several forms of design, the experimental method in this study uses the type of One-Group design pretest-posttest Design conducted in class XI Animation 2 with explanatory text material.

One-Group pretest-posttest Design in this experiment had a pretest before being given treatment, thus the results of the treatment can be known to be more accurate, because it can compare before being given treatment and after being treated. This design can be described as follows.

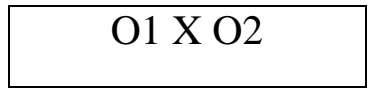

$\mathrm{O} 1=$ Pretest value (before being treated)

$\mathrm{O} 2=$ Posttest value (after being given slowly)

\section{RESULTS AND DISCUSSION}

This research was conducted on $29^{\text {nd }}$ of January until $5^{\text {th }}$ march in senior high school SMK TI Garuda Nusantara Cimahi. The pretest was conducted before the students received the treatment on $29^{\text {nd }}$ of January 2019, and pretest was given after treatment on $5^{\text {th }}$ of march 2019 . The result of the pretest and posttest were analyzed and described in the table, as follow :

\begin{tabular}{|c|c|c|c|c|}
\hline \multirow{2}{*}{ No } & \multirow{2}{*}{ Name of Students } & \multicolumn{2}{|c|}{ Score pre experimentak one group } & \multirow{2}{*}{ Gained } \\
\hline & & Pretest & Posttest & \\
\hline 1 & AMPS & 68 & 88 & 20 \\
\hline 2 & AW & 80 & 90 & 10 \\
\hline 3 & $\mathrm{AH}$ & 60 & 75 & 15 \\
\hline 4 & AA & 60 & 83 & 23 \\
\hline 5 & $\mathrm{AS}$ & 68 & 75 & 7 \\
\hline 6 & DG & 65 & 83 & 18 \\
\hline 7 & DF & 70 & 85 & 15 \\
\hline 8 & $\mathrm{DM}$ & 55 & 79 & 24 \\
\hline 9 & FNR & 63 & 82 & 19 \\
\hline 10 & GBR & 43 & 75 & 32 \\
\hline 11 & HMA & 50 & 78 & 28 \\
\hline
\end{tabular}




\begin{tabular}{lllll}
12 & KR & 65 & 75 & 10 \\
\hline 13 & LE & 60 & 75 & 15 \\
\hline 14 & MFM & 55 & 79 & 24 \\
\hline 15 & MAD & 60 & 75 & 15 \\
\hline 16 & MAH & 60 & 75 & 15 \\
\hline 17 & MK & 60 & 80 & 20 \\
\hline 18 & MAA & 58 & 78 & 20 \\
\hline 19 & MI & 63 & 75 & 12 \\
\hline 20 & MRA & 63 & 83 & 20 \\
\hline 21 & RZR & 65 & 80 & 15 \\
\hline 22 & RM & 60 & 80 & 20 \\
\hline 23 & RF & 62 & 83 & 21 \\
\hline 24 & RMF & 63 & 85 & 22 \\
\hline 25 & SFS & 60 & 87 & 27 \\
\hline 26 & SNA & 55 & 80 & 25 \\
\hline 27 & VAB & 75 & 95 & 20 \\
\hline 28 & WA & 63 & 83 & 20 \\
\hline 29 & YHR & 30 & 75 & 45 \\
\hline 30 & YS & 38 & 72 & 34 \\
\hline 31 & MIN & 45 & 80 & 20 \\
\hline 32 & MRM & 60 & 80 &
\end{tabular}

Table 1.the score of pretest posttest

In the table 1.the score of pretest posttest, based on the table above, pretest the higher score was 80 and the lowest score 30, and the posttest the higher score was 90 and the lowest score 72. Is mean that is there and improvement of students reading comprehension after they had given the treatment.

DATA STATISTICS

DESCRIPTIVE STATISTICS

Descriptive Statistics

\begin{tabular}{|l|r|r|r|r|r|r|r|}
\hline & $\mathrm{N}$ & \multicolumn{1}{|c|}{ Range } & Minimum & Maximum & Sum & Mean & Std. Deviation \\
\hline Pretest & 32 & 50 & 30 & 80 & 1902 & 59.44 & 9.909 \\
Posttest & 32 & 23 & 72 & 95 & 2568 & 80.25 & 5.187 \\
Valid N (listwise) & 32 & & & & & \\
\hline
\end{tabular}

Table2.descriptive statistics result

Based on the table above, the mean of pretest was 59.44 and posttest was 80.25 and the standard devitation of pretest was 9.909 and posttest was 5.187.

NORMALITY TEST 
To finding the data weather it was normal or not the writer used SPSS.21 formula. SPSS calculated two statistics for testing normality, kolmogrov - Smirnov and Shapiro - Wilk.

Tests of Normality

\begin{tabular}{|c|c|c|c|c|c|c|c|}
\hline & \multirow[t]{2}{*}{ postest } & \multicolumn{3}{|c|}{ Kolmogorov-Smirnova } & \multicolumn{3}{|c|}{ Shapiro-Wilk } \\
\hline & & Statistic & $\mathrm{df}$ & Sig. & Statistic & df & Sig. \\
\hline \multirow{2}{*}{ Pretest } & pretest & .241 & 32 & .000 & .901 & 32 & .006 \\
\hline & postest & .157 & 32 & .044 & .926 & 32 & .030 \\
\hline
\end{tabular}

Table3.normality statistics result

Based on the table above, obtained significance data for pretest of $0.006<0.05$, which means that the significance for the pretest value is abnormal because it is less than 0.05 , then the analysis continues to Mann Withney SPSS (U - Test). For posttest, the significance data is $0.030>0.05$, they had be analyze through parametic test $(\mathrm{t}-$ test $)$.

\section{U - TEST}

$\mathrm{U}$ - Test is non-parametric test used to determine the mean difference of 2 free groups if the data scale of the dependent variable is ordinal or interval / ratio but not normally distributed. Basic decision-making in the Mann Withney test :

1. If the value is significant or Asymp. Sig. (2-tailed) smaller than probality of 0.05 then hypothetical or " $\mathrm{H}_{\mathrm{a}}$ accepted"

2. But if the value is significant or Asymp. Sig. (2-tailed) greater than the probability of 0.05 then hypothetical or " $\mathrm{H}_{\mathrm{a}}$ rejected"

The null hypothesis $\left(\mathrm{H}_{\mathrm{a}}\right)$ : "Reciprocal teaching is effective to improve teaching reading comprehension for senior high school"

The result of the test can be showed at the Table4.mann withney statistics result

\begin{tabular}{|l|r|}
\hline \multicolumn{2}{|c|}{ Test Statistics ${ }^{\mathbf{a}}$} \\
\hline Mann-Whitney U & Pretest \\
Wilcoxon W & 22.500 \\
Z & 550.500 \\
Asymp. Sig. (2-tailed) & -6.602 \\
\hline
\end{tabular}

a. Grouping Variable: posttest

Table4.mann withney result

From the table above, the results of the Asymp U-test. Sig. (2-tailed) of 0,000 smaller than 0.05. then, as the basis of the decision making mann-withney test above concluded that "Ha accepted".

T - Test 
$\mathrm{T}$ - test is parametric test took to find the normality distribute. The hypothesis of the test as follows:

The null hypothesis $\mathrm{H}_{\mathrm{o}}$ : "Reciprocal teaching is not effective to improve teaching reading comprehension for senior high school".

\begin{tabular}{|l|r|r|r|r|}
\hline & \multicolumn{1}{|c|}{ One-Sample Statistics } \\
\hline pretest & 64 & Mean & \multicolumn{1}{c|}{ Std. Deviation } & Std. Error Mean \\
postest & 64 & 1.50 & 13.09819 & 1.63727 \\
& 64 & .504 & .063 \\
\hline
\end{tabular}

Table5.one-sample statistics result

One-Sample Test

\begin{tabular}{|c|c|c|c|c|c|c|}
\hline & \multicolumn{6}{|c|}{ Test Value $=80$} \\
\hline & \multirow[t]{2}{*}{$\mathrm{t}$} & \multirow[t]{2}{*}{$d f$} & \multirow[t]{2}{*}{ Sig. (2-tailed) } & \multirow[t]{2}{*}{ Mean Difference } & \multicolumn{2}{|c|}{$\begin{array}{l}\text { 95\% Confidence Interval of the } \\
\text { Difference }\end{array}$} \\
\hline & & & & & Lower & Upper \\
\hline pretest & 6.203 & 63 & .000 & 10.15625 & -13.4281 & -6.8844 \\
\hline postest & 1246.149 & 63 & .000 & 78.500 & 78.63 & 78.37 \\
\hline
\end{tabular}

Table5a.one-sample statistics result

From the table above T-observe pretest 6.203 the posttest 1246.149 and degree of freedom (df) 63 is1.671 its mean that the T-observe is higher than t-table. The sig. (2-tailed) is 0.000 islower than 0.05. its mean the null hypothesis "Reciprocal teaching is not effective to improve teaching reading comprehension for senior high school" was rejected. It can be concluded that teaching reading comprehension using reciprocal teaching strategy was effective.

\section{DISCUSSION}

In this case, after the writer relate this research, the writer finds the results of the data analysis in accordance with the score of the research. The mean of the posttest is higher than mean score pretest. Its shows that there is an improvement students' reading comprehension before and after treatment. In this research, the writer gives treatment six meeting. The first meeting, make student group class consist 6 persons. Students read a report text about Dicerorhinus Sumatrensis. Every group makes notes which includes the words is not understood. There are some words unfamiliar for students which have been found is meaning.

In the second meeting students answer the question multiple choice and essay from about Dicerorhinus Sumatrensis of report text. The next meeting, students make question based on the text to predict the question that will given by teacher. In that case students get more information and new knowledge from the text. It proves a theory that predicting in reciprocal teaching provides an overall rationale for reading confirm or disconfirm self-generated hypothesis. After that until the last meeting, the writer gives another text of report text like mobile phones and bullying for students disccuss to analyze the text. Thus, student get new vocabularies and could read with comprehend.

Based on students' score pretest the higher was 80 and the lowest score 30, and for the posttest the higher score was 95 and the lowestscore is 72 . The sum of pretest 1.902 and sum of posttest 
2.568. and the mean of pretest 59.44 and posttest 80.25 . based on data result above, the writer concludes that reciprocal teaching strategy can improve students' reading comprehension. As describe the mean of posttest was higher than mean of pretest. degree of freedom (df) 63 is 1.671 its mean that the T-observe is higher than t-table. The sig. (2-tailed) is 0.000 islower than 0.05 . its mean the null hypothesis "Reciprocal teaching is not effective to improve teaching reading comprehension for senior high school" was rejected. It can be concluded that teaching reading comprehension using reciprocal teaching strategy was effective.

\section{CONCLUSION}

The use of Reciprocal Teaching was effective in improving reading comprehension. Based on data analysis, it showed the mean of posttest was bigger than pretest $(80.25>59.44)$. In addition, sig (2-tailed) of the data was smaller, the significance value $(0.000<0.05)$ or the null hypothesis was rejected, it can be said' that reciprocal teaching stratefy can improve reading comprehsion for students.

\section{ACKNOWLEDGMENTS}

We thank the family, parents, friends and lecturers who have given us support both morally and materially, so that we can complete and publish our journal.

\section{REFERENCES}

Apsari, Y. (2016). Cloze Passage In Improving Students'reading Comprehension. Eltin Journal, Journal of English Language Teaching in Indonesia, 4(2), 53-62.

Belajar, P. H. (2017). Pengertian Dan Definisi Hasil Belajar Menurut Para Ahli. Www.Wawasan-Edukasi.Web.Id, 1-6.

E. Mulyasa. (2009). Kurikulum Berbasasis Kompetensi (Konsep, Kerakteristik, Implementasi), (Bandung: Remajarosdakarya, 2002). Jurnal Ptm, 9(2), 57-64.

Kamsari. (2013). Peningkatan Keterampilan Membaca Untuk Menemukan Informasi Secara Cepat Dan Tepat Dengan Teknik Memindai Pola Vertikal Dan Horizontal Pada Siswa Kelas Viiia Semester Ganjil Mts Nu Serangan Tahun Pelajaran 2012/2013. Peningkatan Keterampilan Membaca Untuk Menemukan Informasi Secara Cepat Dan Tepat Dengan Teknik Memindai Pola Vertikal Dan Horizontal Pada Siswa Kelas Viiia Semester Ganjil Mts Nu Serangan Tahun Pelajaran 2012/2013, 201.

Parmawati, A. (2018). The Study Correlation Between Reading Habit And Pronunciation Ability At The Second Grade Students Of Ikip Siliwangi. Eltin Journal, Journal of English Language Teaching In Indonesia, 6(1), 46-52.

Parmawati, A., \& Yugafiati, R. (2017). Using Authentic Material To Improve Students'reading Interest (A Classroom Action Research In The Second Semester Students Of Stkip Siliwangi Bandung). Eltin Journal, Journal Of English Language Teaching In Indonesia, $5(1), 1-8$.

Rini, E. L. (1985). Improving Students 'Reading Comprehension Through Email: Ersytarini@Gmail.Com.

Setiyaningsih, A. (2013). The Use Of Problem Based Learning To Improve Students '. Journal Of English Language Teaching, 2(2), 1-8.

Sugiyono. (2015). Metode Penelitian Kuantitatif, Kualitatif Dan R\&D. Bandung: Alfabeta 